\title{
PERAN PENGAWAS DALAM PENINGKATAN KOMPETENSI PEDAGOGIK GURU PENDIDIKAN AGAMA ISLAM SMP NEGERI 10
}

\author{
Harmida Ramadhani Nasution ${ }^{1}$, Rahmadi Ali ${ }^{2}$ \\ ${ }^{1}$ Universitas Islam Negeri Sumatera Utara Medan \\ ${ }^{2}$ Universitas Muslim Nusantara Al Washliyah Medan \\ email: harmidaramadhani@gmai.com \\ email: rahmadiali@umnaw.ac.id
}

\begin{abstract}
The research problem was how the planning, implementation, problems and solving the problems which supervisor did in improving Islamic teachers' pedagogic competencies at Government Junior School 10 Binjai, Binjai City, North Sumatera. The purpose of the study was to describe the planning, implementation, problems and solving the problems which supervisor did in improving Islamic teachers' pedagogic competencies at Government Junior School 10 Binjai, Binjai City, North Sumatera. This research was conducted with qualitative methods. Research data collection was done by using interview, observation and documentation studies. Data analysis was done by using data reduction, data display, and conclusion, that the process took place in a circular during the study. The supervisor's planning in improving Islamic teachers' pedagogic competencies at State Junior High School 10 Binjai, Binjai City, North Sumatera conducted in early academic year and involving supervisors, principal, and the teachers. Planning arranged systematically in the Work Plan Trustees. The implementation of improving Islamic teachers' pedagogic competencies at State Junior High School 10 Binjai, Binjai City, North Sumatera done in two ways: personal approach and group approach. Personal approach consisted of direct class visits, personal meeting and class observation. Group approach consisted of periodical meeting, the empowerment of Islamic Teachers Organization and trainings. Problems faced by Supervisor in improving Islamic teachers' pedagogic competencies at State Junior High School 10 Binjai, Binjai City, North Sumatera were: 1) Technical problems, consisted of urgent unplanned worktrip and the large workfield which reduced meeting intensity with Islamic teachers; and 2) Non technical problems, which consisted of changing of national curriculum and changing of Teaching Plan Form. These several changes caused misunderstood among Islamic teachers. Supervisor solved the problems faced in improving Islamic teachers' pedagogic competencies at State Junior High School 10 Binjai, Binjai City, North Sumatera by building effective communication with teachers, improving his personal performance and empowering Islamic Teachers Organization monthly.
\end{abstract}

Keywords: Islamic education supervisors, pedagogical competence, Islamic education teacher

\section{ABSTRAK}

Rumusan masalah penelitian ini adalah bagaimanakah perencanaan, pelaksanaan, hambatan dan upaya pengawas mengatasi hambatan dalam meningkatkan kompetensi pedagogik guru PAI SMP Negeri 10 Binjai Kota Binjai. Tujuan penelitian adalah untuk mendeskripsikan perencanaan, pelaksanaan, hambatan dan upaya pengawas mengatasi hambatan dalam meningkatkan kompetensi pedagogik guru PAI SMP Negeri 10 Binjai Kota Binjai. Penelitian ini dilaksanakan dengan metode kualitatif. Pengumpulan data penelitian dilakukan dengan menggunakan teknik wawancara, observasi dan studi dokumentasi. Analisis data dilakukan dengan teknik reduksi data, penyajian data, dan kesimpulan yang prosesnya berlangsung secara sirkuler selama penelitian. Perencanaan pengawas dalam meningkatkan kompetensi pedagogik guru PAI SMPN 10 Binjai diawali dengan perencanaan sistematis yang merupakan hasil koordinasi pengawas PAI, pengurus Pokjawas Kota Binjai, Kepala Sekolah dan guru. 
Perencanaan dilakukan pada awal semester ganjil untuk dilaksanakan pada semester ganjil dan genap. Pelaksanaan upaya meningkatkan kompetensi pedagogik guru PAI SMPN 10 Binjai dilakukan dengan dua cara yaitu teknik kelompok dan teknik individu. Teknik individu yang digunakan pengawas adalah supervisi kunjungan kelas, pertemuan pribadi dan observasi kelas. Sedangkan teknik kelompok yang digunakan adalah rapat guru dan pemberdayaan MGMP PAI, dan pelatihan. Hambatan yang dihadapi pengawas dalam upaya meningkatkan kompetensi guru PAI SMPN 10 Binjai berupa hambatan teknis dan non teknis. Hambatan teknis yaitu pelaksanaan supervisi terkendala dengan tugas dinas yang yang tidak terencana sebelumnya dan bersifat urgen, dan luas wilayah kerja pengawas yang luas, sehingga mengurangi intensitas pembinaan terhadap pribadi guru PAI. Hambatan non teknis yaitu kurikulum yang kerap berubah, demikian juga dengan format RPP yang merupakan dokumen wajib guru PAI sebelum mengajar, sehingga menimbulkan kebingungan guru dalam menyusunnya. Upaya pengawas dalam mengatasi hambatan dalam meningkatkan kompetensi pedagogik guru PAI SMPN 10 Binjai yaitu membangun komunikasi yang efektif, meningkatkan kualitas pribadi pengawas dan pemberdayaan MGMP PAI setiap bulannya.

Kata kunci: pengawas PAI, kompetensi pedagogik, guru PAI

\section{A. PENDAHULUAN}

Keberadaan pengawas Pendidikan Agama Islam menjadi urgen dan penting sejalan dengan diterbitkannya Peraturan Menteri Agama No 2 Tahun 2012 tentang Pengawas Madrasah dan Pengawas Pendidikan Agama Pada Sekolah. Peraturan tersebut juga menyatakan tugas-tugas seorang Pengawas PAI.

Sebagaimana dinyatakan Pada Bab 2 pasal 3 ayat 2 bahwa pengawas Pendidikan Agama Islam pada sekolah mempunyai tugas melaksanakan pengawasan Pendidikan Agama Islam. Dan pada pasal 4 ayat 2 dinyatakan bahwa fungsi pengawas PAI meliputi: a. penyusunan program pengawasan PAI; b. pembinaan, pembimbingan, dan pengembangan profesi guru PAI; c. pemantauan penerapan standar nasional PAI; d. penilaian hasil pelaksanaan program pengawas PAI; dan e-pelaporan pelaksanaan tugas kepengawasan.

Berdasarkan Keputusan Menteri Agama Nomor 211 Tahun 2011 tentang Pedoman Pengembangan Standar Nasional Pendidikan Agama Islam dinyatakan bahwa Pengawas Pendidikan Agama Islam harus memahami standar kompetensi pengawas, baik kompetensi kepribadian, supervisi manajerial, supervisi akademik, evaluasi pendidikan, penelitian dan pengembangan, sosial, spiritual, dan kompetensi leadership. Dengan demikian, maka Pengawas Pendidikan Agama Islam mampu mengembangkan model dan pendekatan pengawasan yang komprehensif untuk mendukung iklim pendidikan dan pembelajaran di sekolah yang bermutu.

Peran guru juga sangat penting dalam menentukan keberhasilan pendidikan yang 
dilkukan di dalam sekolah. Maka Guru harus mampu berperan sebagai pengelola dalam proses pembelajaran, dan sebagai fasilitator yang mampu menciptakan suasana proses pembelajaran yang kondusif dan efektif. Selain itu guru juga di tuntut harus memiliki strategi dalam mengorganisasikan kelas dengan baik dan menggunakan metode pembelajaran yang berpariasi Keterampilan-keterampilan di atas merupakan bagian dari kompetensi seorang guru, sehingga bisa melahirkan nilai atau oral yang dibutuhkan pada masyarakat majmuk (Saihu, 2019: 441)

Berdasarkan Permendiknas Nomor 16 Tahun 2007 kompetensi pedagogik guru terdiri atas 37 buah kompetensi, yang dirangkum dalam 10 kompetensi inti, yaitu: menguasai karakteristik peserta didik dari aspek fisik, moral, spiritual, sosial, kultural, emosional,dan intelektual, lalu menguasai teori belajar dan prinsipprinsip pembelajaran yang mendidik, mengembangkan kurikulum yang terkait dengan mata pelajaran yang diampu, menyelenggarakan pembelajaran yang mendidik, memanfaatkan teknologi informasi dan komunikasi untuk kepentingan pembelajaran, menfasilitasi pengembangan dimiliki, berkomunikasi secara efektif, empatik, dan santun dengan peserta didik, menyelenggarakan penilaian dan evaluasi proses dan hasil belajar, memanfaatkan hasil penilaian dan evaluasi untuk kepentingan pembelajaran serta melakukan tindakan reflektif untuk peningkatan kualitas pembelajaran.

Dalam peningkatan komp0etensi guru peran pengawas sangat penting. Hal ini seperti yang disebutkan oleh Asmani bahwa peran supervisor atau pengawas meliputi 4 hal, yaitu: pertama, Pengawas sebagai koordinator; kedua, Pengawas sebagai konsultan; ketiga, Pengawas sebagai pemimpin kelompok; keempat, Pengawas sebagai evaluator, Jamal Ma'mur Asmani (2012:32). Berangkat dari teori tersebut, maka seorang pengawas mutlak diperlukan, mengingat bahwa pengawas merupakan konsultan dan guru bagi para guru.

Pada kenyataannya, peran pengawas dalam peningkatan kompetensi pedagogik guru masih dirasakan belum optimal. Sebagaimana hasil penelitian Sunaryana yang menyebutkan bahwa supervisi akademik yang dilaksanakan oleh Pengawas PAI belum efektif. Hal ini dibuktikan dengan frekwensi kunjungan ke sekolah selama tahun pelajaran 2015/2016 baru terlaksana sekali. Supervisi akademik masih menekankan pada administrasi pembelajaran, sedangkan supervisi kelas belum terlaksana. Pembinaan Pengawas 
kepada guru hanya didasarkan pada hasil pemeriksaan administrasi pembelajaran, Sunaryana (2016).

Namun demikian, Pengawas Pendidikan Agama Islam SMP Negeri 10 Binjai yang berlokasi di kecamatan Binjai Barat Kota Binjai telah menunjukkan kinerja yang berbeda. Berdasarkan wawancara awal yang peneliti lakukan terhadap guru PAI di SMP Negeri 10 Binjai, beliau menyatakan bahwa pengawas PAI secara rutin melaksanakan kunjungan dan pembinaan kepada Guru PAI di SMP tersebut. Sebagaimana dinyatakan oleh seorang guru PAI SMP Negeri 10 Binjai yang mengakui peran aktif pengawas dalam pembinaan guru PAI di SMP Negeri 10 Binjai (wawancara).

Aktivitas pengawasan yang dilakukan pengawas PAI SMP Negeri 10 Binjai juga tidak terhenti pada masa pandemi virus corona ini. Menurut keterangan seorang guru PAI, pengawas masih melaksanakan aktivitas pengawasan dengan menggunakan media teknologi untuk berkomunikasi dengan Guru PAI tentang perkembangan pembelajaran PAI pada saat ini, serta membimbing PAI melaksanakan pembelajaran yang sesuai dengan pola pembelajaran jarak jauh.

Selain itu, indikasi terjadinya peningkatan kompetensi guru PAI di SMP
Negeri 10 Binjai adalah dengan diraihnya beberapa prestasi guru PAI sampai skala Nasional. Bahkan salah satu SMP Negeri di Kecamatan Binjai Barat yaitu SMP Negeri 10 Binjai, terpilih sebagai peringkat 5 Pengelolaan Pendidikan Agama Islam Terbaik se Indonesia pada tahun 2014 yang dilaksanakan oleh Kementerian Agama RI pada kegiatan Apresiasi Pendidikan Islam Tahun 2014.

Upaya pengawas PAI SMP Negeri 10 Binjai untuk tetap melaksanakan peningkatan kompetensi guru PAI di sekolah tersebut, khususnya pada peningkatan kompetensi pedagogik guruguru PAI, menunjukkan bahwa tidak semua pengawas memiliki kinerja yang rendah dalam membina guru-guru PAI. Peran pengawas yang sedemikian dalam pandangan peneliti layak untuk digali lebih jauh untuk menjadi bahan perbandingan bagi pengawas-pengawas Pendidikan Agama Islam di sekolah lain.

Dengan fakta-fakta di atas, peneliti tertarik untuk melaksanakan penelitian lebih lanjut dengan tema "Peran Pengawas dalam Peningkatan Kompetensi Pedagogik Guru Pendidikan Agama Islam SMP Negeri 10 Binjai Kota Binjai”. 


\section{B. TINJAUAN PUSTAKA}

\section{Pengertian Pengawas}

Secara etimologi supervisi atau supervision yang berarti Pengawasan berasal dari bahasa Inggris dan terdiri dari dua kata yaitu super dan vision, yang berarti melihat dengan teliti pekerjaan secara keseluruhan. Sedangkan orang yang melakukan aktifitas supervisi disebut supervisor atau pengawas, Departemen Agama RI (2005:2).

Sedangkan secara terminologi. Menurut Burton dan Bukner dalam Sahertian, supervisi adalah teknik pelayanan yang tujuan utamanya mempelajari dan memperbaiki secara bersama- sama faktor-faktor yang mempengaruhi pertumbuhan dan perkembangan anak. Piet. A (2008:17-18). Dalam konteks tersebut, tujuan utama pelaksanaan supervisi adalah terkait usaha yang dilakukan secara bersama (pengawas dan guru) untuk melakukan perbaikan belajar siswa sesuai dengan tingkat pertumbuhannya.

Asmani menyatakan bahwa secara semantik supervisi adalah pembinaan yang berupa bimbingan atau tuntunan kearah perbaikan situasi pendidikan pada umumnya dan peningkatan mutu mengajar dan belajar pada khususnya, Jamal Ma'mur Asmani (2012:21). Dengan kata lain supervisi adalah pelaksanaan bimbingan dan pembinaan oleh tenaga profesional terhadap guru guna peningkatan kualitas dalam kegiatan mengajar, yang pada akhirnya akan berimplikasi secara langsung pada peningkatan kaulitas dan mutu belajar siswa.

Berdasarkan pendapat-pendapat diatas, dapat disimpulkan bahwa supervisi atau pengawasan pendidikan sebagai tahapan pokok dalam pelaksanaan konsep manajemen, merupakan proses pengamatan dan monitoring terhadap subsistem pada lembaga pendidikan, untuk ketercapaian visi dan misi lembaga atau organisasi pendidikan yang telah dirumuskan. Seluruh stakeholder dalam lembaga pendidikan harus terlibat secara langsung dalam proses pengawasan, agar tidak terjadi penyelewengan kewenangan dan tugas pokok.

\section{Pengertian Pengawas Pendidikan Agama Islam}

Menurut Peraturan Menteri Agama Republik Indonesia Nomor 2 Tahun 2012. Tentang Pengawas Madrasah dan Pengawas Pendidikan Agama Islam pada Sekolah, pada Bab I Ketentuan Umum, pada Pasal 1 ayat (4), menyebutkan bahwa Pengawas Pendidikan Agama Islam yang selanjutnya disebut Pengawas PAI pada sekolah adalah Guru Pegawai Negeri Sipil yang diangkat dalam jabatan fungsional 
pengawas pendidikan agama Islam yang tugas, tanggung jawab, dan wewenangnya melakukan pengawasan penyelenggaraan Pendidikan Agama Islam pada sekolah.

Muhamad Muspawi juga mengungkapkan, bahwa Pengawas Pendidikan Agama Islam merupakan seseorang yang berstatus Pegawai Negeri Sipil pada Kementerian Agama yang ditugaskan untuk mengawasi pelaksanaan Pendidikan Agama Islam di sekolah umum dan penyelenggaraan pendidikan di madrasah dengan melaksanakan penilaian dan pembinaan pada satuan pendidikan pra sekolah, dasar dan menengah (Muspawi, 2018: 634).

Pengawas Pendidikan Agama Islam (PAI) merupakan tenaga kependidikan yang strategik dan penting untuk mengendalikan mutu penyelenggaraan pendidikan Agama Islam pada sekolah, terutama melalui pembimbingan profesi atau supervisi edukatif dan akademik kepada guru Pendidikan Agama Islam (PAI), Achmad Habibullah (2013:46).

\section{Fungsi dan Peran Pengawas Pendidikan Agama Islam}

\section{a. Fungsi Pengawas Pendidikan Agama Islam}

Pada Pasal 3 ayat (2) disebutkan bahwa Pengawas PAI pada sekolah sebagaimana dimaksud dalam Pasal 2 ayat (1) mempunyai tugas melaksanakan pengawasan Pendidikan Agama Islam pada sekolah. Selanjutnya, Pengawas PAI pada sekolah mempunyai fungsi melakukan: a. Penyusunan program Pengawasan PAI; b. Pembinaan, pembimbingan, dan pengembangan profesi guru PAI; c. Pemantauan penerapan standar nasional PAI; d. Penilaian hasil pelaksanaan program pengawasan; dan e. Pelaporan pelaksanaan tugas kepengawasan.

Berdasarkan uraian diatas, fungsi Pengawas PAI berwenang untuk: a. Memberikan masukan, saran, dan bimbingan dalam penyusunan, pelaksanaan, dan evaluasi pendidikan dan/atau pembelajaran Pendidikan Agama Islam kepada Kepala Sekolah dan instansi yang membidangi urusan pendidikan di Kabupaten/Kota; b. Memantau dan menilai kinerja guru PAI serta merumuskan saran tindak lanjut yang diperlukan; c. Melakukan pembinaan terhadap guru PAI; d. Memberikan pertimbangan dalam penilaian pelaksanaan tugas guru PAI kepada pejabat yang berwenang; dan e. Memberikan pertimbangan dalam penilaian pelaksanaan tugas dan penempatan Guru PAI kepada Kepala Sekolah dan pejabat yang berwenang.

Berdasarkan regulasi di atas, maka dipahami bahwa pembinaan guru Pendidikan Agama Islam merupakan salah 
satu fungsi utama keberadaan Pengawas Pendidikan Agama Islam pada sekolah. Selain itu pengawas juga berfungsi untuk membimbing guru PAI dalam menyusun silabus, RPP, dan evaluasi pembelajaran serta membuat saran tindak lanjut yang perlu dilakukan guru PAI.

\section{b. Peran Pengawas Pendidikan Agama Islam}

Menurut pendapat Peter F. Olivia yang dikutip oleh Piet A. Sahartian, bahwa seorang pengawas dapat berperan sebagai: 1) Koordinator; 2) Konsultan; 3) Pemimpin kelompok; 4) Evaluator, Piet A. Sahertian (2008:25)

Dalam pelaksanaan supervisi, karakteristik dan potensi guru yang dihadapi oleh pengawas pasti berbeda-beda, dilihat dari sisi usia dan kematangan, pengalaman kerja, motivasi guru. Maka pengawas harus mampu menerapkan pendekatan dengan guru sesuai dengan karakteristik dan potensinya msing-masing. Apabila pendekatan yang diterapkan idak sesuai dengan karakteristik dan potensi guru maka kegiatan supervisi tidak akan berlangsung dengan efektif.

\section{Ruang Lingkup Pengawasan Pendidikan Agama Islam}

Menurut Sahertian, ruang lingkup pengawasan dilihat dari objek supervisi mencakup: a. $\quad$ Kurikulum; b.
Administrasi; c. Akademik; dan d. Manajerial, Piet A. Sahertian (2008:134)

\section{Pengertian Kompetensi}

Willy Susilo menyatakan bahwa kompetensi adalah kombinasi pengetahuan, kemampuan/keterampilan dan sikap yang dimiliki seseorang sehingga mampu melakukan suatu pekerjaan yang telah dirancang untuk dirinya di masa sekarang maupun di masa yang akan datang, Willy Susilo (2006:6). Pendapat Willy tersebut menekankan pada aspek pengetahuan, keterampilan dan sikap seseeorang dalam melaksanakan pekerjaannya.

Spencer dan Spencer dalam Uhar menyatakan bahwa kompetensi merupakan karakter sikap dan perilaku, atau kemampuan individual yang relatif bersifat stabil ketika menghadapai suatu situasi di tempat kerja yang terbentuk dari sinergi antara watak, konsep diri, motivasi internal serta kapasitas kemampuan intelektual, Uhar Suharsaputra (2010:196). Pandangan di atas menekankan kompetensi terwujud pada sikap dan perilaku seseorang berhubungan dengan pekerjaannya, yang didasarkan pada watak, konsep diri, motivasi pribadi dan kemampuan intelektual dan pengetahuan seseorang.

\section{Kompetensi Pedagogik Guru Pendidikan Agama Islam}

Menurut Murni dalam Aan, kompetensi pedagogik adalah kemampuan 
guru untuk mengelola program pembelajaran di dalamnya mencakup kemampuan untuk mengelaborasi kemampuan peserta didik, merencanakan program pembelajaran, melaksanakan program pembelajaran, dan mengevaluasi program pembelajaran.

Sedangkan menurut Martinis Yamin dan Maisah mengemukakan bahwa kompetensi pedagogik meliputi pemahaman terhadap peserta didik, perencanaan, dan pelaksanaan pembelajaran, evaluasi hasil belajar, dan pengembangan peserta didik untuk mengaktualisasikan berbagai potensi yang dialaminya, Martinis Yamin, dkk (2010:9).

Berdasarkan pendapat-pendapat di atas dapat disimpulkan bahwa Kompetensi Pedagogik adalah kemampuan memahami karakteristik peserta didik, perancangan dan pelaksanaan pembelajaran, evaluasi hasil belajar, dan pengembangan peserta didik dalam mengaplikasikan berbagai potensi yang dimilikinya.

\section{METODE PENELITIAN}

Jenis penelitian ini adalah penelitian kualitatif yaitu penelitian yang bersifat deskriptif. Jadi prosedur penelitian ini, akan menghasilkan data deskriptif, berupa katakata tertulis atau lisan dari orang-orang dan perilaku yang dapat diamati. Penelitian deskriptif kualitatif ini bertujuan untuk mendeteksikan suatu keadaan atau fenomena-fenomena secara apa adanya.

Pengumpulan data yang dibutuhkan dalam penelitian ini dilakukan dengan menggunakan teknik yang disesuaikan dengan situasi dan kondisi lapangan penelitian, pengumpulan data melibatkan terutama melalui pengamatan atau observasi, wawancara mendalam dan pengkajian dokumen.

\section{Observasi}

Pengamatan langsung atau observasi diperlukan untuk membantu dalam mengumpulkan data di lapangan. Dari observasi ini peneliti berharap akan mendapatkan data dan gambaran secara rinci. Dalam pelaksanaan observasi, peneliti akan mengamati proses pelaksanaan supervisi yang dilakukan oleh Pengawas PAI dalam meningkatkan kompetensi pedagogik Guru Pendidikan Agama Islam SMP Negeri 10 Binjai Kota Binjai.

Dengan teknik ini peneliti mempelajari seluruh aspek permasalahan yang sedang diteliti sehingga dapat diketahui secara empiris fenomena yang terjadi dalam kaitannya dengan persoalan pelaksanaan supervisi akademik dalam meningkatkan kinerja guru PAI. 


\section{Wawancara}

Target wawancara dilakukan kepada: Pengawas PAI SMP Negeri 10 Binjai, Pengurus Pokjawas PAI Kota Binjai, Kepala Sekolah, dan para guru PAI SMP Negeri 10 Binjai Kota Binjai. Wawancara dilakukan peneliti dengan mengajukan beberapa pertanyaan yang berkaitan dengan pelaksanaan supervisi dan kompetensi pedagogik guru PAI. Pertanyaan yg diajukan peneliti tidak menyulitkan narasumber untuk menjawabnya dan memberikan keleluasaan kepada narasumber untuk menyatakan apa yang narasumber alami sesuai dengan fakta dan penomena yg ada.

\section{Studi Dokumen}

Dalam penelitian ini yang dijadikan dokumen meliputi: Program kerja pengawas PAI terutama terkait pelaksanaan supervisi, Program Kerja Pokjawas, Program Kerja Kepala Sekolah, Progran kerja guru, Daftar kunjungan kelas, daftar kehadiran guru, buku tamu, Format Penilaian kompetensi pedagogik guru PAI dan laporan program peningkatan kompetensi guru melalui seminar dan workshop.

\section{PEMBAHASAN}

SMPN 10 Binjai adalah lembaga pendidikan yang didirikan atas dasar kebutuhan dan keinginan masyarakat Kecamatan Binjai Barat pada tahun 1994. Keinginan masyarakat tersebut didasari ketiadaan Sekolah Menengah Pertama sebagai sekolah lanjutan yang berstatus Negeri. Pemerintah melalui Dinas Pendidikan dengan segera merespon keinginan masyarakat tersebut dengan mendirikan Sekolah Menengah Pertama diatas area dengan luas $7.760 \mathrm{M}^{2}$ dan luas bangunan $1.796 \mathrm{M}^{2}$, yang terletak di Jalan Rambutan Ujung No 33 Kelurahan Bandar Senembah, Kecamatan Binjai Barat Kota Binjai Sumatera Utara.

Pada tahun 1996 SMPN 10 Binjai mulai dioperasikan dengan melakukan penerimaan siswa baru sesuai dengan jumlah ruang kelas yang tersedia saat itu. SMPN 10 Binjai yang telah terakreditasi "A" pada pelaksanaan Penilaian Sekolah dan Akreditasi dari BAN-SMP pada tahun 2016.

Temuan pertama, Perencanaan pengawas dalam meningkatkan kompetensi pedagogik guru Pendidikan Agama Islam SMP Negeri 10 Binjai dilakukan berdasarkan rencana kerja yang sistematis. Sedangkan pelaksanaan pembinaan bagi guru PAI dilakukan dengan upaya pendampingan guru dalam menyusun skenario pembelajaran dari mulai menyusun rencana pembelajaran sampai 
dengan pelaksanaan evaluasi pembelajaran.

Dan evaluasi pembinaan dilakukan dengan melaksanakan program pemantauan dan tindak lanjut. Baik perencanaan, pelaksanaan dan evaluasi pembinaan akademik bagi guru PAI melibatkan pengawas PAI, kepala sekolah, Wakil Kepala Sekolah Bidang Kurikulum dan Guru PAI.

Temuan kedua, pelaksanaan pengawas Pendidikan Agama Islam dalam meningkatkan kompetensi pedagogik guru Pendidikan Agama Islam SMP Negeri 10 Binjai Kota Binjai dilaksanakan dengan memaksimalkan dua teknik, yaitu teknik individu dan teknik kelompok. Teknik individu yang digunakan adalah supervisi kunjungan kelas, pertemuan pribadi, observasi kelas. Sedangkan teknik kelompok yang digunakan adalah pertemuan dan pelatihan MGMP, rapat guru. Alasan mendasar penggunaan kedua teknik ini adalah efektifitas dan efisisensi, serta pemberdayaan kompetensi pengawas dan kepala sekolah.

Temuan ketiga, Hambatan yang dihadapi pengawas Pendidikan Agama Islam dalam meningkatkan kompetensi pedagogik guru Pendidikan Agama Islam SMP Negeri 10 Binjai Kota Binjai berupa penentuan waktu pembinaan oleh pengawas dan kepala sekolah. Pengawas selain sebagai pemimpin dalam organisasi pendidikan juga merupakan anggota masyarakat. Kendala teknis yang terjadi pada saat pembinaan adalah belum maksimalnya pelaksanaan teknik kelompok dalam bentuk seminar dan pelatihan bagi guru PAI yang memang membutuhkan dana tidak sedikit.

Temuan keempat, Cara pengawas Pendidikan Agama Islam mengatasi hambatan dalam meningkatkan kompetensi pedagogik guru Pendidikan Agama Islam SMP Negeri 10 Binjai Kota Binjai adalah dengan segala upaya kendala-kendala tersebut dapat diminimalisir dengan jalinaan komunikasi yang efektif antara seluruh stakeholder di SMP Negeri 10 Binjai. Selain itu pemberdayaan Sumber Daya Manusia di SMP Negeri 10 Binjai dalam pelaksanaan supervisi menjadi solusi yang paling logis. Kepala sekolah dan pengawas PAI senantiasa didaulat sebagai nara sumber dalam beberapa even pembinaan melalui forum MGMP PAI.

Mencermati temuan pertama bahwa perencanaan pengawas dalam meningkatkan kompetensi pedagogik guru PAI di SMP Negeri 10 Binjai dilakukan dengan tahapan-tahapan manajemen, yang diawali dengan perencanaan terukur. Peran Pengawas PAI dengan didukung oleh Tim Pokjawas dan masukan dari Kepala SMPN 
10 Binjai sangat dominan dalam kaitannya dengan perencanaan pembinaan. Temuan ini sejalan dengan Peraturan Menteri Agama No 2 tahun 2012 Bab II pasal 4 tentang tugas dan fungsi pengawas PAI pada sekolah, terkait dengan penyusunan program pengawasan PAI.

Pelaksanaan pembinaan bagi guru dipahami sebagai bantuan akademik yang diberikan pengawas dan Kepala Sekolah sebagai bagian dari aktifitas supervisi. Pembinaan dimaksudkan untuk meningkatkan dan memperbaiki kinerja guru. Dalam hal ini, baik Kepala Sekolah maupun guru dalam pelaksanaan pembinaan harus memperlakukan guru sebagai orang yang berpotensi untuk maju dan berkembang lebih baik, sehingga tidak terkesan pelaksanaan supervisi hanya mencari kesalahan guru dalam melaksanakan tugas tetapi lebih diarahkan pada proses pembinaan sebagai bantuan. Intinya pelaksanaan pembinaan harus didasari dengan prinsip demokrasi, yaitu pelayanan bantuan yang diberikan kepada guru dengan membangun kebersamaan untuk saling sharing of idea, sharing of experience, memberi support dan saling memberi stimulan, Jasmani Asf, dkk (2013:47).

Dan tahapan selanjutnya dari program pembinaan adalah pelaksanaan evaluasi pembinaan guru PAI di SMP Negeri 10 Binjai yang direfleksikan dalam bentuk evaluasi pembinaan akademik. Evaluasi pembinaan dilakukan untuk melihat ketercapaian pelaksanaan pembinaan di SMP Negeri 10 Binjai oleh Pengawas PAI dan stakeholder lainnya. Kegiatan pembinaan yang telah dirancang sedemikian baik harus mampu dilaksanakan secara nyata di lapangan seperti yang diharapkan dalam rencana.

Mecermati temuan kedua bahwa dalam pelaksanaan supervisi dalam meningkatkan kinerja guru PAI di SMP Negeri 10 Binjai, baik pengawas PAI dan Kepala Sekolah menggunakan teknik individu dan teknik kelompok. Kedua teknik ini dianggap mampu memberikan pencerahan dan perubahan secara simultan kepada guru PAI dalam melakssanakan tugas pokoknya.

Pelaksanaan supervisi merupakan bantuan yang diberikan pengawas kepada guru, agar proses pembelajaran dapat terlaksana dengan baik. Tugas guru yang sangat komplek harus mampu dipahami oleh pengawas, karenanya dibutuhkan keterampilan dan pengetahuan pengawas untuk mengidentifikasi permasalahan yang dihadapi guru baik secara individu maupun kelompok.

Salah satu kompetensi yang lazim dimiliki seorang pengawas atau supervisor 
adalah menguasai variasi teknik yang akan diterapkan dalam pembinaan guru melalui kegiatan supervisi. Setiap guru dipastikan memilki kebutuhan yang berbeda untuk meningkatkan kinerjanya. Namun tidak menutup kemungkinan guru-guru memiliki kebutuhan pembinaan pada subjek yang sama.

Teknik individu dalam pelaksanaan supervisi yang dilakukan di SMP Negeri 10 Binjai adalah supervisi kunjungan kelas, pertemuan pribadi dan observasi kelas. Kunjungan dan observasi kelas merupakan kegiatan pembinaan yang dilakukan pengawas dan kepala sekolah dalam rangka mengamati proses pembelajaran, sehingga diperoleh data untuk program pembinaan bagi guru.

Dalam pelaksanaan supervisi kunjungan kelas dan observasi terdapat 4(empat) tahapan. Langkah pertama adalah tahap persiapan. Pada fase ini supervisor menyusun rencana kunjungan dan menentukan waktu, tujuan serta sasaran kunjungan kelas.Pada tahap kedua, adalah tahap pengamatan, dimana supervisor melakukan pengamatan terhadap berlangsungnya proses pembelajaran. Pada tahap ketiga adalah tahap akhir, dimana supervisor dan guru membuat perjanjian untuk mendiskusikan hasil pengamatan. Dan yang keempat adalah tahapan tindak lanjut, yaitu berupa pengambilan keputusan terhadap program lanjutan.

Sedangkan teknik individu berupa pertemuan pribadi dilakukan dengan tujuan memberikan kemungkinan terpecahnya permasalahan yang dihadapi guru. Dalam pertemuan ini supervisor memberikan peluang bagi guru untuk sharing terhadap problematika dalam KBM. Dan melalui pertemuan pribadi akan terbangun keakraban yang pasti akan berdampak positif bagi komunikasi interpersonal antara supervisor dengan guru.

Pada teknik supervisi kelompok, pengawas dan kepala sekolah fokus pada pemberdayaan MGMP dan rapat sekolah. Melalui wadah profesi guru PAI berupa Musyawarah Guru Mata Pelajaran PAI diharapkan efektifitas supervisi dalam meningkatkan kinerja guru dapat terpenuhi.

Upaya pemberdayaan MGMP adalah wujud urgensi sebuah jaringan kerja yang dapat dijadikan model dalam melakukan pembinaan terhadap guru untuk meningkatkan kualitas kinerjanya. Dalam forum ini para guru dapat belajar untuk evaluasi diri dan belajar untuk mengkomunikasikan masalah yang dialami dalam kegiatan belajar mengajar.

Pengawas dan Kepala Sekolah punya peran besar dalam MGMP, selain sebagai internal supervisor, kompetensi mereka 
juga diberdayakan dalam forum ini. Hal ini menjadi satu peluang bagi pengawas dan kepala sekolah untuk mengembangkan potensi kepemimpinannya dan kompetensi profesionalnya.

Berkenaan dengan teknik supervisi kelompok dalam bentuk rapat guru, baik pengawas maupun kepala sekolah berperan sebagai pemimpin rapat. Peran ini tentu tidak mudah, karena harus mampu memfasilitasi dan mengakomodasi kepentingan peserta rapat atau dewan guru. Dalam kegiatan rapat guru, kepala sekolah dan pengawas memberikan masukan dan saran rasional kepada guru untuk meningkatkan kinerjanya serta menyampaikan informasi dan issue terkait pembelajaran.

Mencermati temuan ketiga, hambatan yang dihadapi pengawas dalam meningkatan kompetensi pedagogik guru PAI SMPN 10 Binjai pelaksanaan penilaian kinerja guru PAI di SMP Negeri 10 Binjai yaitu dalam pelaksanaan supervisi guru PAI di SMP Negeri 10 Binjai terdapat beberapa temuan masalah yang dihadapi oleh pengawas supervisor dan guru sebagai supervisee berupa permasalahan yang bersentuhan dengan teknis dan non teknis.

Hambatan utama yang dihadapi adalah kurikulum yang sering berubah-ubah, dalam perjalanan dunia pendidikan di indonesia, salah satu upaya pemerintah untuk mencapai tujuan pendidikan yang di harapkan adalah melakukan perubahan kurikulum pendidikan. Dampak dari perubahan kurikulum tersebut bisa membuat mutu pendidikan menjadi menurun dan perubahan kurikulum yang begitu cepat menimbulkan masalah baru. Dengan perubahan itu seorang guru tentunya mempelajari dan beradaptasi menyesuaikan bahkan belajar lagi dengan kurikulum yang baru, jika seorang guru belum bisa menguasai secara maksimal kurikulum tersebut maka proses pembelajaran akan mempengaruhi menurunnya prestasi siswa, hal ini di karenakan siswa tidak dapat menyesuaikan diri dengan sistem pembelajaran pada kurikulum yang baru.

Hambatan lainnya adalah model RPP yang berbeda-beda. RPP merupakan terjemahan ide kurikulum yang berdasarkan silabus yang di kembangkan pada tingkat nasional ke dalam bentuk rancangan proses pembelajaran untuk direalisasikan dalam proses pembelajaran. Setiap guru dalam satuan pendidikan berkewajiban menyusun RPP secara lengkap dan sistematis. Upaya perwujudan perancangan RPP yang implementatif memerlukan kemampuan yang komprehensif. Kemampuan itulah yang dapat mengantarkan guru menjadi 
tenaga kerja yang profesional. Dalam perancangan RPP kemampuan setiap guru berbeda-beda tentunnya model RPP dari masing-masing guru itu pun berbeda-beda.

Selain itu, masalah yang dianggap prinsip adalah terkait masalah pembagian waktu pengawas dan kepala sekolah. Waktu-waktu yang telah disepakati untuk pelaksanaan pembinaan dan peningkatan kompetensi pedagogik terhalang dengan tugas dinas yang mendadak atau hal-hal yang lain tidak dapat diprediksi, seperti menempatkan diri sebagai bagian dari tatanan masyarakat. Hal ini karena guru dan supervisor mempunyai tiga jenis tugas, yaitu tugas dalam bidang kemanusiaan, tugas dalam bidang profesi dan tugas dalam bidang kemasyarakatan, Usman (2016:64).

Mencermati temuan keempat bahwa solusi yang dilakukan pengawas dalam mengatasi hambatan peningkatan kompetensi akademik guru PAI SMPN 10 Binjai yang paling ideal bagi hambatanhambatan tersebut dapat dilakukan dengan cara pendekatan, bimbingan, pengarahan sehingga guru PAI merasa terbimbing, terarah bahkan kehadiran seorang pengawas sangat diharapkan oleh guru PAI. Dalam pelaksanaan pembinaan optimalisasi pengawas sekolah perlu ditingkatkan. Hal ini terlihat dari keberhasilan guru yang mampu menyusun silabus dan merancang RPP sesuai dengan kebijakan kurikulum.

Solusi yang utama adalah komunikasi yang efektif antara seluruh komponenen yang terlibat dalam pelaksanaan supervisi untuk meningkatkan kompetensi pedagogik guru. Komunikasi yang efektif adalah komunikasi yang dibangun atas dasar saling percaya, sikap suportif, emphati, simpati, dan sikap terbuka.

Dalam konteks ini, peneliti justru melihat bahwa hambatan dan kendala yang dihadapi, baik oleh supervisor maupun supervisee dapat menjadi peluang bagi supervisor dan guru yang disupervisi untuk mengembangkan dirinya. Artinya supervisor, baik kepala sekolah atau pengawas dituntut untuk senantiasa mengembangkan kemampuan dan keilmuannya. Pengawas dapat berperan sebagai fasilitator dan nara sumber dalam kegiatan pelatihan dan workshop dalam rangka memenuhi kebutuhan pengetahuan guru PAI. Dalam hal ini tentu tidak mudah berperan sebagai nara sumber, karena harus melengkapi diri dengan persiapan ilmu dan mental.

Dan persoalan luasnya wilayah kerja serta jumlah pengawas yang sangat terbatas, hal ini merupakan persoalan kebijakan Kementerian Agama untuk melakukan rekrutmen pengawas. Namun 
bukan berarti proses supervisi harus terhenti karena persoalan tersebut. Musyawarah Guru Mata Pelajaran PAI dapat dijadikan wadah profesional dengan pengelolaan dan manajemen yang baik. Baik Pengawas, Kepala Sekolah dan Guru PAI dapat mengkonstruksi sifat kepemimpinan dari organisasi ini.

Menurut peneliti solusi cepat yang dapat dilakukan Kementerian Agama dalam menyikapi kekurangan jumlah pengawas adalah dengan meningkatkan intensitas pelaksanaan kegiatan pelatihan profesional bagi pengawas.

\section{E. KESIMPULAN}

1. Perencanaan pengawas dalam meningkatkan kompetensi pedagogik guru PAI SMPN 10 Binjai diawali dengan perencanaan sistematis yang merupakan hasil koordinasi pengawas PAI, pengurus Pokjawas Kota Binjai, Kepala Sekolah dan guru. Perencanaan dilakukan pada awal semester ganjil untuk dilaksanakan pada semester ganjil dan genap.

2. Pelaksanaan upaya pengawas dalam meningkatkan kompetensi pedagogik guru PAI SMPN 10 Binjai dilakukan dengan dua cara yaitu teknik kelompok dan teknik individu. Teknik individu yang digunakan pengawas adalah supervisi kunjungan kelas, pertemuan pribadi dan observasi kelas. Sedangkan teknik kelompok yang digunakan adalah rapat guru dan pemberdayaan MGMP PAI, dan pelatihan.

3. Hambatan yang dihadapi pengawas dalam upaya meningkatkan kompetensi guru PAI SMPN 10 Binjai berupa hambatan teknis dan non teknis. Hambatan teknis yaitu pelaksanaan supervisi terkendala dengan tugas dinas yang yang tidak terencana sebelumnya dan bersifat urgen, dan luas wilayah kerja pengawas yang luas, sehingga mengurangi intensitas pembinaan terhadap pribadi guru PAI. Hambatan non teknis yaitu kurikulum yang kerap berubah, demikian juga dengan format Rencana Pelaksanaan Pembelajaran (RPP) yang merupakan dokumen wajib guru PAI sebelum mengajar, sehingga menimbulkan kebingungan guru dalam menyusunnya.

4. Upaya pengawas dalam mengatasi hambatan dalam meningkatkan kompetensi pedagogik guru PAI SMPN 10 Binjai yaitu membangun komunikasi yang efektif, meningkatkan kualitas pribadi pengawas dan pemberdayaan MGMP PAI setiap bulannya. 


\section{DAFTAR PUSTAKA}

Asf, Jasmani dan Syaiful Mustofa. (2013). Supervisi Pendidikan: Terobosan Baru dalam Peningkatan Kinerja Pengawas Sekolah dan Guru. Jogjakarta: Ar-Ruzz Media.

Asmani, Jamal Ma'mur. (2012). Tips Efektif Supervisi Pendidikan Sekolah. Jogjakarta: Diva Press.

Departemen Agama RI. (2005). Kepengawasan Pendidikan,. Jakarta: Dirjen Kelembagaan Agama Islam.

Habibullah, Achmad. (2013). Kinerja Pengawas Pendidikan Agama Islam. Edukasi Islami: Jurnal Pendidikan Islam, 11(11).

Keputusan Menteri Agama Nomor 211. (2011). tentang Pedoman PengembanganStandar Nasional Pendidikan Agama Islam.

Muspawi, M. (2019). Peran Kinerja Pengawas Pendidikan Agama Islam Sekolah Dasar Bagi Peningkatan Kompetensi Pedagogik Guru Pendidikan Agama Islam. Ta'dib: Jurnal Pendidikan Islam, 8(2).

Pahlevi, Akhmad Riza. (2020). Peran pengawas dalam meningkatkan pedagogik Guru PAI di SMP 10 Binjai. Hasil Wawancara Pribadi: 21 Juli 2020.

Peraturan Menteri Agama Nomor 2 Tahun 2012 Tentang Pengawas Madrasah dan Pengawas Pendidikan Agama Pada Sekolah.

Permendiknas Nomor 16 Tahun 2007 tentang Standar Kualifikasi Akademik dan Kompetensi Guru.

Saihu dan Baeti Rohman. (2019). Pembentukan Karakter Melalui Model Pendidikan Transformatife Learning pada Santri di pondok Pesantren Nurul
Ikhlas Bali. Edukasi Islami: Jurnal Pendidikan Islam, 08(02).

Sahertian, Piet A. (2008). Konsep Dasar dan Teknik Supervisi Pendidikan Dalam Rangka Pengembangan Sumber Daya Manusia. Jakarta: Asdi Mahasatya.

Suharsaputra, Uhar. (2010). Administrasi Pendidikan. Bandung: PT Refika Aditama.

Sunaryana. (2016). Upaya Pengawas PAI dalam Meningkatkan Kompetensi Pedagogik Guru PAI di SMP Negeri 2 Bayudono Kabupaten Boyolali. Tesis: Pasca Sarjana IAIN Surakarta.

Susilo, Willy. (2006). Advanced Quality Audit. Jakarta: Vorqista.

Usman. (2016). Manajemen Teori Praktik dan Riset Pendidikan. Jakarta: Raja Grafindo Persada.

Yamin, Martinis dan Maisarah. (2010). Standarisasi Kinerja Guru. Jakarta: GP Press. 